\title{
Analisis Anggaran Biaya Operasional Dan Anggaran Pendapatan Terhadap Kinerja Keuangan Berdasarkan Return On Asset (ROA) Pada Counter Crocs TM Di Kota Malang
}

\author{
Febriana Maria Luan ${ }^{1}$, Luh Dina Ekasari², Ahmad Mukoffi ${ }^{3}$ \\ Universitas Tribhuwana Tunggadewi Malang \\ *Korespondensi: luanfebri5@gmail.com
}

\begin{abstract}
The purpose of this research is to find out the operational budget and revenue budget affect the level of financial performance at the crocs tm counter in Malang City. The design of this research is to use a quantitative descriptive method, in this research the data sources used are secondary data and primary data. The data collection techniques used in this research are interviews and observation. The data analysis technique used is quantitative descriptive analysis. It was found in the results of this research that operational variables can have a significant effect on the change ratio, while the revenue budget has no significant effect on the change ratio in Counter Crocs TM in Malang City, Malang City.

Keywords: Operational Cost Budget and Revenue Budget on Financial Performance Based on Return On Assets (Roa)
\end{abstract}

\section{PENDAHULUAN}

Pada umum industri memmilki sebuah tujuan ialah uantuk dapat memaksimalkan sebuah tujuan yang mana telah diadakan dalam proses perencanaan. Olehn karena itu setiap industri akan selau senantiasa dalam memaksimalkan serta dapat mengefektifkat serta efesiensi dalam melakukan aktifitas bekerja. Adapun salah satu faktor yang terpenting dalam proses perencanaan serta pengendalian ialah biaya. Baiaya yang akan dimiliki oleh pihak industri akan ssellau diyakini dalam proses di masah yang akan datang. Aktifitas disalah satu bidang inilah yang tidak akan terpisahkan baik itu dalam melakukan seuah tahapan untuk menggapai sebuah tujuan sehingga dalam memproseskan dalam penyususnan informasih, baik yang mana bersifat kendali bahkan sampai pada sebuah taksiran.

Pada dasarnya sebauh industri mempunya misi ialah untuk dapat mengoptimalkan serta dalam pencapaian sebuah tujuan yang mana akan direnanakan, baik itu dalam tujuan jangka panjang serta jangka yang pendek. Terdapat aktiftas dalam sebuah industri diberbagai segi diantaranya SDMsistempemasaran serta bagian finansial dapat saling bergantung dalam merahi sbeuah impian dalam mensuksekan industri yang berkelanjutan. Pada dasarnay sebuah industri akan melakukan sbeuah planing dalam berlandaskan pada sebuah asa dalam tahap perencanaan yang mana dianggap perlu dalam pencapaian sbeuah tujuan. Salah satu faktor yang akan dianggap sangat terpenting ialah pendanaan. Pendanaan merupakan salah satu yang akandimilki oleh sebuah industri dalam memperyakini para tenaga kerja.

doi: https://doi.org/10.51544/jma.v6i2.1963

(C) 2021 Jurnal Mutiara Akuntansi. This is an open access article under the CC BY-SA license Website: http://e-journal.sari-mutiara.ac.id/index.php/JMA/ 
Adanya sebuah planing terhadap pendanaan sama sekali ntidak menggapai, akan secara teoritis akan dapat dikatakan bahwa tingkat kinerja finansial pada sbeuah industri akan sangat memberikan pengaruh. Hal ini akan sellau disebabkan terjadinya pendapatan kas serta tingkat persediaan serta aset yang lainnya. sebuah industri akan berdiri dengan mempunyai sbeuah tujuan dnegan cara memiliki sbeuh keuntungan yang jauh lebih efektif. Oleh sebab itu industri dapat dikatakn bahw aindustri akan berkembang dalam tingkat kinerja finasialserta akan dapat dimiliki berdasarkan pada sebuah analisa pada informasij finansial industri. Sebagai mana diungkap oleh (Sawir.2001) yang menyatakan bahwa data yang akan natinya dimilki serta dapat dianalisa berdasarkan dengan laopran keuangan sehingga secara tidaklangsung apakah dalam sebuah industri dpat berkembang atau akan mengalami kemacetan pada sisi finasnsial. (Trisna Widuri, 2012) meytakan bahwa return on asset atau sering dikenal dengan nama ROA akan secara tidak langsung akan dapat menilai tingkat industri secara efektif serta efisien dalam memenuhi kewajiban baik itu dalam jangka pendek maupun panjnag.

Counter Crocs TM Malang merupakan merupakan salah satu perusahaan yang mengelolah atau menjual berbagai produk-produk sepatu sandal merk crocs yang ada di Malang, atau menyediakan berbagai produk sepatu mulai anak-anak hingga dewasa dengan harga dan kualitas yang terjamin. Kondisi pencapaian target dalam sejumlah tahun daapr mengisyaratkan perusahaan menyelami kendala bagian dalam taktikdalam merangcang sebuar planing pendanaan yang mana kan diatur semkasimal mungkin oleh pihak industri. Berdasarkan pada kajian teoritis yang mana akan dijelasakan bahwa sebuah pendanaan atau angran dapat memberikan sebuah pengaruh yang sijgnifikan terhadap tinggihnya utangb yang dimilki oleh pihak industri.

Salah satu faktor yang paling dominan ialah sistem perencanaan serta tingkat pengendalian pada sebuah industri ialah pendanaan. Faktor yang terpenting pada sebuah indsutri ialah pengendalian, karena sebuah pengendalian pada sebuah industri ialah sistem perencanaan pada anggaran. Perencanaan anggaran yang dilakuakn oleh industri dapat dikatakan sebagai salah satu faktor yang paling dominan dlaam memaksimalkan tingkat kinerja dalam sebuh indutri. Sistemperencanaan paad sebuah anggran dapat dikatakan sebgai salah satu pengaturan yang dapat dianggap sangat susah dalam merahi sebuah mipi pada sbeuah indsurti dimasa yang kan datang. Sebuah pelatihan terkait dengan perencanaan sebuah anggaran ini sangat berkesenambunagan yang mana berdasarkan pada tingkat pelaksanaan serta pada pengukuan perbelanjaan. Apa bila terdapat sebuah problema yang ada, secara tidak langsung akan dapat membingungkan dalam sebuah organisasi akan dapat diselesaikan apa bila tergantung pada sebuah pengaturan yang jauh lebih tepat.

\section{TINJAUAN PUSTAKA Anggaran}

Supriyono (2015) menyatakan bahwa angrana ialah salah satu tahap proses perencanaan yang akan dilakukan secara terperinci bahkan sampai pada sistematis serta dapat diatur secara kuantitatif. Sebuah anggaran pada biaya operasional yang mana mirip ialah seluruh sisttem perencanaan baik yang berkaitan dnegan anggaran operasional ialah industri serta melakukan aktifitas peroses penjalan pada sebuah hasil produksi yang ada pada industri denga maksut dan tujauan ialah untuk dapat menjalan roda pada organisasi indutri (Rudianto 2011 : 116). Rudianto 2011; 116 menyatakan bahwa sistem perencanaan ialah pihak industri akan melakuan sebuah proses perencanaan dalam menggapai 
tingkat pendapatan dalam jangka waktu yang ditentukan. Sedangkan menurut Nafarin (2013 :11) meyatakan bahwa budget dapat dikatakan sebagai slah satu proses perencanaan yang dapat terorganisir dalam sebuah program, akan tetapi bukan saja dapat dinyatakan dalam satuan rupiah akan tetapi akan dapat dikatakan dalam bentuk jasa atau barang.

\section{Rasio Return On Asset (ROA)}

Sebagaimana diungkapkan oleh Ang (2012) yang menaytakan bahwa return on asset atau sering dikatakan dengansebagai ROA merukaan salah satu rasio diantara tingkat pendapatan yang ajuh lebih bersih sesudah pajak terhadap asset. Return on asset atau sering dikatakan dengansebagai ROA juga dpaat dikatakan sebagai salah satu dalam tingakat pengembalian yang mana akan dimilki oleh pemegang saham dari kelebihan penanaman modal yang dibuat. Dendrawijya (2003) meyatakan bahwa semakin meningkat pada return on asset atau sering dikatakan dengansebagai ROA di sebuah industri maka secara tidak langsung juga semakin membaik pada situasi industri yang kaan dinilai dari aspek asset. Dlam tujaun untuk pencapai keuntungan yang ada, maka salah satu cara ilaah pihak pemegang saham snagt diharapkan dalam memilki sebuah keuntungan dari deviden, oleh karena itu dalam segi ekonomi konvensial jenis penenemam modal ialah dlaam memeilki keuntungan yang maksimal, oleh karena itu apabila sebuah saham yang dpaat dihasilkan oleh pihak deviden yang tinggi maka tingkat ketertarikan penanaman modal akan secara tidak langsung akan dapat menghasilkan keuntungan dari pihka deviden. Rendahnya maupun tinggihnya return on asset atau sering dikatakan dengansebagai ROA akan dipergantungkan pada sistem pengoprasian pada asst industri oleh pimpinan yang mana akan dapat menggambarkan tingkat efesisensi dari operasi industri. .

\section{Kinerja Keuangan}

Mahsun (2006:25) yang menyatakan bahwa tingkat kinerja dapat dikatakan sebagai slah satu gambaran dalam mencapai sebauh aktifitas dalam mewujudkan sebuah tujuan organisasi.Tingkat kinerja keuangan ialah salah satu bagian finansial yang mana akan berkaitan dnegan sebauh pendapatan bahkan sampai pada tingkat pengeluaran dalam situasi operasional secara menyeluruh. Pada dasarnya data keuangan pada sebuah industri baik itu sacara internal maupun eksternal. (Sucipto 2003 : 6). Menyatakan bahwa return on asset atau sering dikatakan dengansebagai ROA dapat digunakan dalam mengukur tingkat kinerja finansial terhadap meningkatkan tingkat penghasilan dalam keuntungan serta dalam mengukur aktiva yang akan dimilki. return on asset atau sering dikatakan dengansebagai ROA dapat dikatakan sebagai slah salah satu rasio pada laba sesudah pajak terhadap total asset. Semakin meningkat return on asset atau sering dikatakan dengansebagai ROA akan secara memaksimalkan untuk dapat memenuhi kewajiban pada masah yang akan datang.

\section{Analisis Kinerja Keuangan}

Salah satu kinerja lapotran keunagn ialah dapat digunakan untuk dapat melihat tingkat kinel pada sebuah industri, analisis sbeuah laporan keuangan dapat dibedahkan menjadi beberapa bagian diantaranay :

a. Analisa sebuah laporan keungan terhadap sebuah permbandingan

b. Tendensi pada sebuab posisi 
c. Analisa pada sbeuah tingkat presentase

d. Analisa pada penggunaan sebuah modal kerja

e. Analisa pada sumber penggunaan paka kas

f. Analisa terhadap sebuah rasio keuangan

g. Analisa pada laporan perubahan modal

\section{METODE PENELITIAN}

Dalam riset ini menggunakan riset kuantitatif, metode yang digukan ialah metode surfey serta kuesioner. Teknik pengumpulan data pada riset ini ialah observasy, interview serta dokumentasi, data yang digunakan ialah data sekunder serta data primer. Teknik analisa data yang digunakan ialah regresi linier berganda.

\section{HASIL DAN PEMBAHSAN}

\section{Analisis Deskritif}

Sebuah anlisa deskripsi antara variabeldengan maksut untuk dapat melihat pada ni;ai maksimum,standar deviasi, mean serta nilai rata-sata. Analisa deskritif dapat disajikan pada tabel berikut ini :

Tabel 1

Uji Validitas Dan Reabilitas Setiap Variabel

\begin{tabular}{|l|c|c|c|c|}
\hline \multicolumn{7}{|c|}{ Descriptive Statistics } \\
\hline \multicolumn{1}{|c|}{ Variabel } & Minimum & Maximum & Mean & Std. Deviation \\
\hline $\begin{array}{l}\text { Anggaran Operasional } \\
\text { Variabel }\end{array}$ & 12584376,00 & 458883819,00 & 67386310,0600 & 101158265,10000 \\
\hline Anggaran Penerimaan & 12617709,00 & 159528529,00 & 65615655,8900 & 31180699,26000 \\
\hline
\end{tabular}

Sebagaimana pada hasil analisa data pada tabel tersebut, sehingga dapat dinyatakan bahwaanggaran variabel berdasarkan pada nilai minimum 12584376,00, nilai maximum sebesar 458883819,00, mean sebesar

67386310,0600 , sedangkan pada nilai standar deviasi sebesar 101158265,10000.Anggaran penerimaan berdasarkan pada nilai minimum 12617709,00, nilai maximum sebesar 159528529,00, mean sebesar 67386310,0600 , sedangkan pada nilai mean sebesar 65615655,8900, dan pada nilai satandar deviasi sebesar 101158265,10000 .

\section{Ujia Asumsi Klasik}

\section{Uji Asumsi Normalitas}

Adapun maksut dan tujuan diadakan pengujian normalitas ini ialah untuk dapat melihat apakah data pada riset ini berdistribusi normal atu tidak. Dan dapat disajikan pada gambar berikut ini :

Gambar1

Uji Asumsi Normalitas

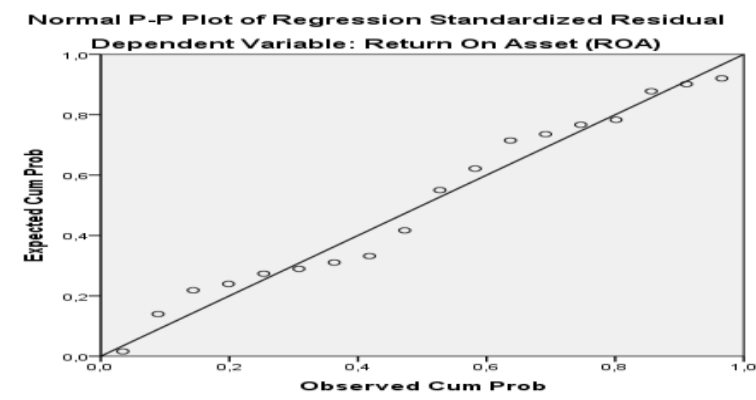

Sebagaimana pada hasil analisa data yang dilakukan, sehingga dapat menyatakan bahwa bwa data pada riset ini dinyatakan normal, hal tersebut dapat 
dinyatakan bahwa terdapat penyebaran titik-titik pada garis diagonal dan dapat dinyatakan bahwa data yang digunakan dalam riset ini berdistribusi normal

\section{Uji Asumsi Multikoliniearitas}

Pengujian multikolinearitas bertujuan untuk dapat mengalisa, apakah data tersebut dinaytakan terjadinya multikolinearitas dalam model ini atau tidak, oleh karena itu dalam pengujian tersebut dapat disajikan pada tabel berikut ini

Tabel 2

Hasil Uji Multikolinieritas

\begin{tabular}{|l|c|c|}
\hline \multirow{2}{*}{ Variabel bebas } & \multicolumn{2}{|c|}{ Collinearity Statistics } \\
\cline { 2 - 3 } & Tolerance & VIF \\
\hline Anggaran Operasional Variabel & 0,719 & 1,391 \\
\hline Anggaran pemasaran & 0,719 & 1,391 \\
\hline
\end{tabular}

Pada hasil anilisa yang ditemukan pada tabel tersebut, sehingga dapat menyatakan bahwa :

a. Nilai tolerance $\left(\mathrm{X}_{1}\right)$ yakni 0,719 , sedangkan pada VIF sebesar 1,391

b. Nilai tolerance $\left(\mathrm{X}_{2}\right)$ yakni 0,719 , sedangkan pada VIF sebesar 1,391

Berdasarkan pada sasil anilisa yang ditemukan, sehingga dapat ditemukan bahwa pada variabel independen lwbih kecil dari 10,00, oleh karena itu dapat dinyatakan bahwa tidak terdapat gejalan multikolinearisat pada model regresi ini.

\section{Uji Asumsi Heteroskedastisitas}

Pengujian heterokedastisitas digunakan untuk dapat menguji apakah dalam model ini terdapat gejala heteroskedastisitas atau tidak, sehingga dapat disajikan pada gambar berikut ini

Gambar 2

Uji Asumsi Heteroskedastisitas

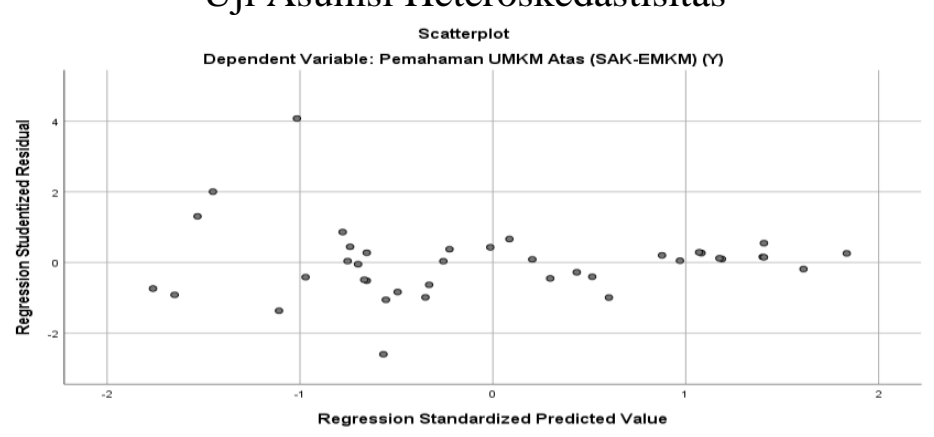

Berdasarkan gambar diatas dan dikatakan bahwa tidak tidak adanya gejala heteroskedastisitas dalam model ini, hal ini dapat dibuktikan bahwa nilai 0 dari sumbu X dan sumbu Y dan terdapat pola yang jelas dari penyebaran data.

\section{Uji Asumsi Autokorelasi}

Uji autokorelasi bertujuan untk dapat menguji dalam model ini apak terdapat gejala autokorelasi atau tik, oleh karena pengujian autokorelasi dapat disajikan pada tabel berikut ini :

Tabel 3

Hasil Uji Autokorelasi

\begin{tabular}{|c|c|c|c|c|c|}
\hline \multicolumn{7}{|c|}{ Model Summary $^{\mathbf{b}}$} \\
\hline Model & $\mathrm{R}$ & R Square & $\begin{array}{c}\text { Adjusted R } \\
\text { Square }\end{array}$ & $\begin{array}{c}\text { Std. Error of the } \\
\text { Estimate }\end{array}$ & Durbin-Watson \\
\hline 1 &, $293^{\mathrm{a}}$ &, 086 &,- 036 & $\begin{array}{c}20700264,9500 \\
0\end{array}$ & 1,437 \\
\hline
\end{tabular}

http://e-journal.sari-mutiara.ac.id 
Sebagaimana pada hasil analisa pada pada tabel tersebut, sehingga dapat dinyatakan bahwa data dinyatakan tidak terjadi gejala autokorelasi karena nilai Durbin Watson $(\mathrm{d})=1,937$ terletak antara -4 sampai +4 maka dapat disimpulkan data tidak terjadi autokorelasi.

\section{Analisis Regresi}

Tujuan diadakan sebuah analisa regresi linier berganda ini ialah untuk dapat menguji hipotesis, serta dapat mengetahui pengaruh antara variabel independen teerhadap valiabel dependen.

Tabel 4

Hasil Uji Linier Berganda

\begin{tabular}{|l|c|c|c|c|c|}
\hline Variabel & $\begin{array}{c}\text { Unstandardized } \\
\text { Coefficients } \\
(\mathrm{B})\end{array}$ & $\begin{array}{c}\text { Standardized } \\
\text { Coefficients } \\
\text { (Beta) }\end{array}$ & $\mathrm{t}_{\text {hitung }}$ & Sig & Keterangan \\
\hline $\begin{array}{l}\text { Anggaran Operasional } \\
\text { Variabel }\left(\mathrm{X}_{1}\right)\end{array}$ & 0,044 & 0,216 & 4,861 & 0,003 & Signifikan \\
\hline $\begin{array}{l}\text { Anggaran Penerimaan } \\
\left(\mathrm{X}_{2}\right)\end{array}$ & 0,104 & 0,160 & 0,635 & 0,535 & $\begin{array}{c}\text { Tidak } \\
\text { Signifikan }\end{array}$ \\
\hline$R$ Square $=0,086$ & \multicolumn{3}{|l}{} \\
\hline
\end{tabular}

Sebagaimana hasil analisa regresi linier berganda tersebut, oleh karena itu dalam pengembangan persamaan regresi dapat disajikan pada rumus sebagai berikut :

$$
\begin{gathered}
\mathrm{Y}=\mathrm{a}+\mathrm{b}_{1} \mathrm{X}_{1}+\mathrm{b}_{2} \mathrm{X}_{2}+\mathrm{e} \\
\mathrm{Y}=4,290+0,216 \mathrm{X}_{1}+0,160 \mathrm{X}_{2}
\end{gathered}
$$

Adapun interpretasi dari hasil persamaan regresi ialah sebagai berikut :

Konstanta sebesar 4,290, yang mana melambangkan bahwa variabel $\left(\mathrm{X}_{1}\right)$, dan $\left(\mathrm{X}_{2}\right)$ pada kinerja keuangan $(\mathrm{Y})$ nilainya adalah $86 \%$.

a. Koefisien regresi variabel $\left(\mathrm{X}_{1}\right)$ memiliki nilai sebesar 0,216 yang artinya bahwa apabila pada variabel bebas tetap dan nilai anggaran operasional mengalami kenaikan, kinerja keuangan (Y) akan mengalami peningkatan sebesar $21,6 \%$.

b. Koefisien regresi variabel $\left(\mathrm{X}_{2}\right)$ memiliki nilai sebesar 0,160yang artinya bahwa apabila pada variabel bebas tetap dan nilai anggaran penerimaan mengalami kenaikan, kinerja keuangan (Y) akan mengalami peningkatan sebesar $16,0 \%$.

\section{Pengujian Hipotesis}

\section{Uji (Uji F)}

Adapun maksut dan tujuan analisa pengujian hipotesi atau uji $\mathrm{F}$ ialah : intuk mengetahui secara bersama-sama antar avriabel independen berpengaruhb pada variabel dependen, aleh karena dapat disajikan pada tabel berikut ini :

Tabel 5

Uji Kelayakan Model (Uji F)

\begin{tabular}{|l|r|r|r|c|c|c|}
\hline \multicolumn{7}{|c|}{ ANOVA $^{\text {a }}$} \\
\hline \multicolumn{2}{|l|}{ Model } & Sum of Squares & df & Mean Square & F & Sig. \\
\hline \multirow{2}{*}{$\begin{array}{l}\text { Regressio } \\
\mathrm{n}\end{array}$} & 602005897300000, & 2 & 301002948700000,000 & 10,04 &, $001^{\mathrm{b}}$ \\
& 000 & & & 7 & \\
\cline { 2 - 7 } & Residual & $\begin{array}{r}627514536000000 \\
000\end{array}$ & 15 & 428500969100000,000 & & \\
\cline { 2 - 7 } & Total & $\begin{array}{r}7029520433000000 \\
0000\end{array}$ & & & & \\
\hline
\end{tabular}


Adapun hasil analisa pada tabel tersebut sehingga dapat dinyatakan bahwa nilai $F_{\text {hitung }}>F_{\text {tabel }}(10,047>5,432)$, sedangkan pada tingkat sig $0,001(\mathrm{p}<0,050)$, sehingga dapat dinyatakan bahwa variabel X1 serta X2 dapat memberikan pengaru secara simultan kepadap kinerja keuangan (Y)pada Counter Crocs TM Di Kota Malang.

\section{Uni (t)}

Adapun maksut dan tujuan analisa pengujian hipotesi atau uji $\mathrm{T}$ ialah : intuk mengetahui secara individual antar avriabel independen berpengaruhb pada variabel dependen, oleh karena dapat disajikan pada tabel berikut ini :

Tabel 6

Hasil Analisis Uji (Uji t)

\begin{tabular}{|l|c|c|c|c|c|}
\hline \multicolumn{1}{|c|}{ Variabel } & $\begin{array}{c}\text { Unstandardi } \\
\text { zed } \\
\text { Coefficients } \\
(\mathrm{B})\end{array}$ & $\begin{array}{c}\text { Standardized } \\
\text { Coefficients } \\
\text { (Beta) }\end{array}$ & $\mathrm{t}_{\text {hitung }}$ & Sig & Keterangan \\
\hline $\begin{array}{l}\text { Anggaran Operasional } \\
\text { Variabel }\left(\mathrm{X}_{1}\right)\end{array}$ & 0,044 & 0,216 & 4,861 & 0,003 & Signifikan \\
\hline $\begin{array}{l}\text { Anggaran Penerimaan } \\
\left(\mathrm{X}_{2}\right)\end{array}$ & 0,104 & 0,160 & 0,635 & 0,535 & $\begin{array}{c}\text { Tidak } \\
\text { Signifikan }\end{array}$ \\
\hline
\end{tabular}

Adapun hasil pengujian sevara individual antara variabel serta hasil perhitungan dapat diinterpretasi sebagai berikut :

1. Adapun variabel anggaran operasional variabel (X1) berpengaruh terhadap rasio perubahan pada Counter Crocs TM Di Kota Malang Kota Malang hal ini mengakibatkan karena nilaithitung $>$ ttabel $(4,861>2.131)$ sedangkan pada tingkat sig sebesar 0,003 ( $\mathrm{p}<0,05)$.

2. Adapun variabel anggaran penerimaan (X2) tidak berpengaruh terhadap rasio perubahan pada Counter Crocs TM di Kota Malang Kota Malang hal ini mengakibatkan karena nilaithitung > ttabel $(0,635<2.131)$ dengan nilai signifikan sebesar $0,535(\mathrm{p}>0,05)$

\section{Pembahasan}

\section{Pengaruh Anggaran Operasional Terhadap Kinerja Keuangan}

Berdasarkan dengan hasil pengujian hipotesi, sehingga dapat dinyatakan bahwa pada variabel $\mathrm{X} 1 \mathrm{t} \mathrm{t}_{\text {hitung }}>\mathrm{t}_{\text {tabel }}(4,861>2.131)$ sedangkat pada tingkat sig sebesar 0,003 ( $\mathrm{p}<0,05)$. Sehingga dapat dinyatakan bahwa pada variabel anggaran operasional memberikan pengaruh yang signifikan terhadap kinerja keuangan, hasil rsiet ini sejalan dengan riset yang dilakukan olah dan menyatakan bahwa (Sigit Aryatama dan Deny Ismanto, 2017) dan menyatakan bahwa anggaran pada sebauh biaya operasional sama sekali tidak dapat memberikan sbeuah pengaruh pada kinerja keunagan

\section{Pengaruh Anggaran PenerimaanTerhadap Kinerja Keuangan}

Berdasarkan dengan hasil pengujian hipotesi, sehingga dapat dinyatakan bahwa pada variabel $\mathrm{X} 1 \mathrm{t}_{\mathrm{t}}$ hitung $>\mathrm{t}_{\text {tabel }}(4,861>2.131)$ sedangkat pada tingkat sig sebesar 0,003 ( $\mathrm{p}<0,05)$.Sehingga dapat dinyatakan bahwa pada variabel angarab penerimaan tidak memberikan pengaruh yang signifikan terhadap kinerja keuangan, hasil rsiet ini sejalan dengan riset yang dilakukan oleh (Maya Widyana Dewi, 2019) dan menyatakan bahwa Pendapatan (X2) berpengaruh signifikan terhadap kinerja keuangan berdasarkan Return On Asset (ROA) pada perusahaan Konstruksi yang terdaftar di Bursa Efek Indonesia (BEI) pada tahun 2015-2017 


\section{KESIMPULAN}

Berdasarkan hasil penelitian dan pembahasan pada bab sebelumnya maka dapat disimpulkan sebagari berikut :

1. Perputaran anggaran operasional variabel berpengaruh signifikan terhadap return on asset (ROA) pada Counter Crocs TM Di Kota Malang, hal tersebut dapat dibuktikan dengan biaya perbandingan pada nilai thitung $>$ ttabel

2. Anggaran penerimaan tidak berpengaruh signifikan terhadap return on asset (ROA) pada Counter Crocs TM Di Kota Malang, hal tersebut dapat dibuktikan dengan biaaya perbandingan pada nilai thitung $>$ ttabel

\section{DAFTAR PUSTAKA}

Ang, Robert. 2012, Buku Pintar Pasar Modal Indonesia (The Intelligent Guide To Indonesian Capital Market). Edisi Pertama. Mediasoft Indonesia. Jakarta.

Arief, M. Rudianto. 2011. Pemrograman Web Dinamis Menggunakan PHP dan MySQL. Yogyakarta. Andi Offset.

Dendawijaya, Lukman. 2003. Manajemen Perbankan. Jakarta : Ghalia Indonesia.

Mahsun, Mohamad. 2006. Pengukuran Kinerja Sektor Publik : Cetakan Pertama. Yogyakarta : Penerbit BPFE-Yogyakarta.

Maya Widyana Dewi, 2 Indra Lila Kusuma. (2019). Analisa Pengaruh Biaya Operasional dan Pendapatan Terhadap Kinerja Keuangan Berdasarkan Rasio Return On Asset (ROA) pada Perusahaan Jasa Konstruksi Yang Terdaftar Di Bursa Efek Indonesia Tahun 2015-2017. Jurnal Akuntansi Dan Pajak, 20(1), DOI: http://dx.doi.org/10.29040/jap.v20i1.559.

Nafarin, M. 2013. Penganggaran Perusahaan. Edisi ketiga, Cetakan kedua, Buku 1. Jakarta : Salemba Empat

Sugiyono. 2015. Metode Penelitian Ku ntitatif, Kualitatif dan R\&D. Bandung: Alfabeta.

Sawir, Agnes, 2001. Analisis Kinerja Keuangan dan Perencanaan Keuangan Perusahaan, PT. Gramedia Pustaka Utama, Jakarta

Sucipto. 2003. "Penilaian Kinerja Keuangan." Jurnal Akuntansi. Universitas Sumatera Utara.Medan.

Sigit Aryatama dan Deny Ismanto. (2017). ANALISIS ANGGARAN BIAYA OPERASIONAL DAN ANGGARAN PENDAPATAN TERHADAP KINERJA KEUANGAN BERDASARKAN RETURN ON ASSET (ROA) PADA PT MADUBARU YOGYAKARTA TAHUN 2012-2016. JURNAL FOKUS, 7(1), 60-66.

Trisna Widuri (2012), "Analisis Kinerja keuangan Berdasarkan Rasio Profitabilitas dan Z-Score Model (Studi Empiris pada PT. Indofood Sukses Makmur, Tbk)", http://publikasi.uniska-kediri.ac.id. 